\title{
Introduction: Conflict, Co-operation and the Cameron-Clegg Government
}

\author{
Judi Atkins \\ Coventry University \\ Email: judi.atkins@ coventry.ac.uk
}

Following the inconclusive result of the last general election, David Cameron made a 'big, open and comprehensive offer' to Nick Clegg to form a partnership government. Four days later, on 11 May 2010, Britain had its first peacetime coalition since the 1930s. Despite widespread predictions to the contrary, the Conservative-Liberal Democrat government has survived for a full parliamentary term. While its period in office was marked by bitter disagreements over issues such as constitutional reform and Europe, it is equally clear that the two parties were able to work well together in other areas, notable among which are education and foreign policy. This raises a number of questions. Why did certain initiatives prove to be particularly contentious? Conversely, why was co-operation on other policies relatively straightforward? How did the two leaders seek to manage conflict within and between their respective parliamentary parties? What was the longer term impact of the Coalition on Britain's constitutional arrangements?

It was to address these questions that the contributors to this special section participated in a conference supported by a British Academy/Leverhulme Small Research Grant (award no: SG121411) and The Political Quarterly, which took place at Congress Centre, London in January 2015. As May's general election looks set to be the most unpredictable in a generation, with a hung parliament seemingly the most likely outcome, the event also provided a timely opportunity to reflect on the experiences of the Cameron-Clegg government and to identify lessons for the partners in a future coalition. Given the damage 
sustained by the Liberal Democrats during their time in government, it is unsurprising that most of these lessons are addressed to the smaller party (or indeed parties). More broadly, the articles explore some of the issues that will confront the next government whatever its composition, such as the future of the Union and the nature of Britain's engagement with both Europe and the wider world.

Three themes emerged from the conference, the first of which is the centrality of ideology in creating conflict and facilitating co-operation. Coalition governments bring together parties with different traditions and values, which in turn give rise to divergent goals and policy priorities. As a result, the partners need to find common ideological ground if they are to reach agreement and work effectively together. The extent to which they succeed in this will affect the coalition throughout its term of office, from the policy programme agreed at its formation to the passage of legislation through Parliament and, finally, the dissolution stage. For the Conservative-Liberal Democrat government, the ideological proximity of senior figures from both parties facilitated co-operation on the Coalition's overarching goal of reducing the UK's budget deficit, as well as on legislation such as the Fixed Term Parliaments Act (2011) and on the question of whether to intervene in Libya and Syria on humanitarian grounds.

A second, related theme is that conflicts were more likely to occur within, rather than between, the Coalition's constituent parties. This is largely attributable to the ideological gap between the two leaders and their parliamentary parties, and indeed the past five years have seen unprecedented levels of backbench rebellion. For the Conservatives, the divisions between modernisers and traditionalists, and between 'hard' and 'soft' Eurosceptics, led to dissent on issues such as same-sex marriage and Britain's relationship with the EU. These conflicts were exacerbated by a perception that the party leadership had made too many concessions to the Liberal Democrats, which caused considerable resentment among 
Conservative MPs. Meanwhile, the ideological differences between Orange Book Liberal Democrats and the social democratic wing of the Party led to backbench disquiet about the leadership's acceptance of the Conservatives' deficit reduction strategy, and to parliamentary rebellions over, for instance, the trebling of university tuition fees and the Health and Social Care Bill. These examples highlight the need for the effective management of intra-party dissent, which in turn is critical to maintaining a leader's authority and preserving coalition unity.

The third theme emerging from these articles is the importance of differentiation. Although inter- and intra-party conflict is undoubtedly problematic for senior Coalition figures, it is clear that differences can be mobilised to promote unity and create a sense of shared purpose. This was a key function of the narrative of Britain's 'debt crisis', which united the two parties behind the cause of deficit reduction while distinguishing their approach from the 'fiscal incompetence' of the previous Labour governments. Differentiation is also necessary for the preservation of the parties' identities while they govern together. This concern is particularly acute for the junior partner, which may prioritise coalition unity over maintaining its distinctive identity. Motivated by a desire to prove that partnership government can work, the Liberal Democrat leadership pursued a strategy of co-operating with the Conservatives while endeavouring to keep conflict to a minimum. However, they would pay a heavy price for this decision in terms of influence, visibility and electoral appeal.

My article shows how the common ideological ground between Conservative modernisers and Orange Book Liberal Democrats enabled the new government to create and project an image of unity. Drawing on the core values of their parties, David Cameron and Nick Clegg announced that the Coalition would be guided by the principles of freedom, fairness and responsibility in its mission to give Britain the strong, stable government it needed. Although the concept of fairness would soon be set aside, their shared belief in 
freedom, responsibility and a small state enabled senior Coalition figures to develop a crisis narrative around Britain's economic problems. This narrative fused party values with a construction of the 'national interest' and united Conservatives and Liberal Democrats behind the cause of deficit reduction, while differentiating them from the 'irresponsible' Labour Party that had allegedly caused the financial crisis. Through frequent repetition the narrative rapidly gained traction with the electorate, whose lingering doubts over Labour's economic competence may well play a role in shaping the outcome of May's general election.

Coalition unity is vital at the formation stage, but there is a danger that the smaller party will become too closely identified with the senior partner and lose its electoral distinctiveness. Libby McEnhill demonstrates that this occurred in the area of welfare policy, where the Liberal Democrats sacrificed their commitment to social justice for the sake of government cohesion. She argues that the decision to place only one junior minister in the Department for Work and Pensions severely curtailed Liberal Democrat influence, making it difficult to distinguish the Party's contribution. Although they attempted to assert their distinctive identity through a partial rejection of the 'bedroom tax' and by highlighting areas where they had restrained the Conservatives, these strategies failed to give a clear sense of what the Liberal Democrats stand for. Consequently, McEnhill proposes that the smaller party in a future UK multi-party government should invest in visibility, perhaps by adopting a 'depth', rather than 'breadth', approach to the allocation of ministerial portfolios.

The Liberal Democrats similarly struggled to exert an influence over the direction of the Coalition's policy on Europe. Eunice Goes attributes this in part to their decision to pursue a 'breadth' strategy in the distribution of portfolios, but she also calls attention to Cameron's difficult relationship with Conservative backbenchers. The ideological division between 'hard' and 'soft' Eurosceptics ensured that intra-party conflict predominated on this issue, which in turn was compounded by Cameron's apparent lack of authority over his MPs. 
In a bid to maintain coalition unity, the Liberal Democrats co-operated with the senior partner and sought to minimise disagreement with the parliamentary Conservative party. However, as Goes points out, this strategy again brought a loss of electoral distinctiveness. She therefore suggests that, if the general election produces another Conservative-led coalition, the Liberal Democrats should insist on controlling or sharing equally the portfolio with responsibility for renegotiating the UK's terms of EU membership. This would enable them to increase their influence in such an important area, while preserving their distinctive identity.

In contrast, the sphere of foreign policy remained relatively free from coalition tensions. Timothy J. Oliver shows that while the Liberal Democrats have long been in favour of humanitarian intervention, it was only under Cameron's leadership that the Conservatives adopted a pro-interventionist stance. The eruption of the Arab Spring in December 2010 brought the two leaders' interventionist impulses to the fore, and Oliver highlights the overlaps between Cameron and Clegg's justifications for military action. These arguments emphasised the need to alleviate civilian suffering first in Libya and then in Syria, and contrasted the proposed interventions with the 2003 Iraq war. The two leaders thus sought to differentiate their approach from that of New Labour, and to rally the support of their parties for military action. While some backbenchers were critical of the arguments presented to them, few MPs from the three main parties objected to the principle of humanitarian intervention per se. So, whatever the outcome of the general election, intervention on humanitarian grounds is likely to feature on the foreign policy agenda of next government.

Another issue with important implications for the next parliament is the constitutional future of the UK. In the wake of the 'no' vote in the Scottish independence referendum, Cameron announced that further devolution of competencies to Scotland must be accompanied by an answer to the West Lothian Question. This was an attempt to neutralise dissent among his backbenchers over the offer of devo-max, and it put the matter of English 
votes for English laws firmly centre stage. In his article, Richard Hayton argues that the command paper containing proposals to address the West Lothian Question reflected not only a lack of agreement at the top of the Coalition, but also a diversity of opinion among Conservative MPs. For Hayton, this indicates that party management concerns have prevented the development of a coherent approach to the future of the constitution. Nonetheless, a cross-party consensus is emerging that the West Lothian Question must be answered, though in the short term the nature of this response is heavily dependent on the result of the forthcoming general election.

These debates over the future of the Union challenge the majoritarian vision of democracy that predominates in the UK. However, Oonagh Gay, Petra Schleiter and Valerie Belu contend that the Coalition itself has compounded this challenge with its amendments to the UK's governing and constitutional conventions. Although the Coalition introduced machinery designed to facilitate inter-party bargaining and manage dissent, the need for the partners to co-operate has caused tensions within their parliamentary parties. In response to the new imperative for compromise, the party leaderships moved away from traditional majoritarian approaches to managing internal conflict and adopted a more negotiated strategy. A second important change is the Fixed-term Parliaments Act, which gives Parliament a greater role in forming, sustaining and terminating governments. This again points towards a more participatory approach to governance that is founded on negotiation, and so further relaxes the UK's majoritarian practices. Gay, Schleiter and Belu suggest that this trend will persist if the 2015 general election produces another hung parliament and that, should two-party politics continue to decline, pressure for a move towards a more proportional vision of democracy is likely to mount.

Finally, Ben Yong and Tim Bale review the options available to Labour if it emerges from the general election as the largest party in a hung parliament. These are: a minority 
government, either on its own or with at least one partner, or a majority coalition with another party (or parties). Given that the precedents for minority government in the UK are not encouraging, Yong and Bale argue that Labour should strive to form a majority coalition if the parliamentary arithmetic permits. After all, the Conservatives benefited substantially from their time in government with the Liberal Democrats, as they were able to command a majority in the House of Commons and implement many of their policies. Conversely, the impact of the junior partner was limited, both in government and in the eyes of the electorate, to the detriment of the Liberal Democrats' electoral distinctiveness and popularity. On the basis of these considerations, Yong and Bale conclude that Labour's best option is a majority coalition because, as the larger party, it can reap the benefits of public visibility and relatively stable government.

Whatever the outcome of May's general election, the experience of the ConservativeLiberal Democrat government demonstrates that a hung parliament need not lead to political instability. It also shows that, despite initial scepticism, coalition government can work in the UK. This is important because it is becoming increasingly difficult for a single party to command a majority in the House of Commons, due to partisan dealignment, the growing public disillusionment with Labour and the Conservatives, and the rising popularity of smaller parties such as the Greens and UKIP. As such, it seems highly likely that the UK will have more coalition governments in the future. It is therefore hoped that the articles in this special section will offer useful lessons for subsequent coalitions, while enhancing understanding of the competing dynamics of conflict and co-operation at work within the Cameron-Clegg government. 